\title{
Timing and Tempo of Dolerite Sill Emplacement into the Karoo Basin during the Toarcian
}

\author{
GAYNOR, S.P. ${ }^{*}$, SchaltegGer U. ${ }^{1}$, SVEnSEN, H. ${ }^{2}$, \\ POLTEAU, S. ${ }^{2}$
}

${ }^{1}$ Dept. of Earth Sciences, University of Geneva, Switzerland, *sean.gaynor@unige.ch

${ }^{2}$ Centre for Earth Evolution and Dynamics (CEED), University of Oslo, Norway

Eruptions of Large Igneous Provinces (LIPs) are commonly correlated with global climate change, and environmental, as well as biological, crises. These short-lived events, typically much less than $5 \mathrm{Ma}$, can erupt more than 1 $\mathrm{Mkm}^{3}$ of volcanic rocks, while potentially also emplacing over $100,000 \mathrm{~km}^{3}$ of upper crustal intrusions. In sedimentary basins, intrusions associated with LIP's are commonly preserved as dikes and sills. Detailing the duration and pace of these high flux magmatic events has, however, been complicated by a lack of high-precision geochronology. This is crucial to understand, as they represent some of the most rapid upper crustal magmatic accretion mechanisms in Earth's history. We focus on the Karoo LIP in southern Africa as a natural laboratory for testing models how such intrusive complexes emplace. The LIP is comprised of a suite of basaltic lava flows, sills, dike swarms, and was emplaced during the early Toarcian. Approximately $340,000 \mathrm{~km}^{3}$ of sills are interlaid within Karoo Basin sedimentary rocks. Differential uplift, erosion and availability of drill core material allows for sampling of the entire sub-volcanic succession.

We report new high-precision $\mathrm{U}-\mathrm{Pb}$ zircon ages for sills emplaced from base to top of the Karoo Basin. Using these data, we are able to address several fundamental questions of LIP emplacement: (1) can we corroborate the anticipated short $\left(10^{4}-10^{5} \mathrm{kyr}\right)$ duration of intrusive magmatism, and (2) the high intrusive magma flux of the Karoo LIP; (3) is there is a relationship between age and emplacement depth of sills within the basin; and (4) is it justified to correlate the intrusion of the LIP with global climate change at this level of precision? These data indicate that the $340,000 \mathrm{~km}^{3}$ of intrusive magmas were emplaced in approximately $500 \mathrm{ka}$, solidifying new mafic upper crust through a downward stacking assembly, and that the entirety of intrusive magmatism was emplaced within the uncertainty of the Toarcian oceanic anoxic event. 